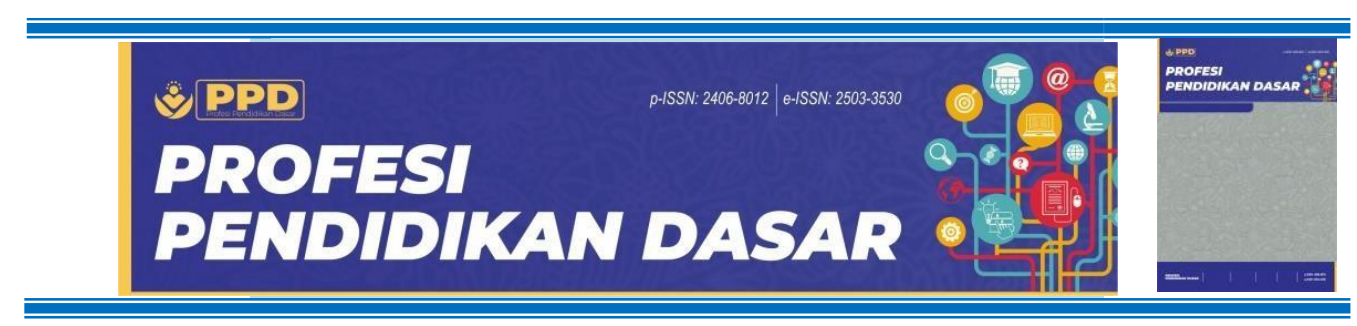

\title{
Communication Skills Profile of Elementary Teacher Education Students in STEM-based Natural Science Online Learning
}

\author{
Duhita Savira Wardani ${ }^{1 *}$, Jajang Bayu Kelana ${ }^{1}$ \& Zingiswa Mybert Monica Jojo ${ }^{2}$ \\ ${ }^{1}$ Institut Keguruan dan IImu Pendidikan Siliwangi, Cimahi, Indonesia \\ ${ }^{2}$ University of South Africa, South Africa \\ *Email : duhita@ikipsiliwangi.ac.id
}

\begin{tabular}{|c|c|}
\hline \multicolumn{2}{|c|}{$\begin{array}{l}\text { Submitted: 2021-03-05 } \\
\text { Accepted: 2021-12-16 } \\
\text { Published: 2021-12-20 }\end{array}$} \\
\hline Keywords: & Abstract \\
\hline $\begin{array}{l}\text { elementary } \\
\text { education; } \\
\text { communication } \\
\text { skills; } \\
\text { stem; } \\
\text { online learning; } \\
\text { natural science }\end{array}$ & $\begin{array}{l}\text { This study aimed to determine the communication skill profile of Elementary } \\
\text { Teacher Education (ETE) students enrolled in natural science online learning- } \\
\text { based STEM. Pre-experimental research with a one-shot case study design was } \\
\text { used in this study. The study's sample consisted of } 25 \text { ETE students from a } \\
\text { university in Cimahi. Observation and documentation were the techniques used } \\
\text { in this study. The paired sample t-test was used to analyze the data. The } \\
\text { descriptive analysis and hypothesis testing with the t-test were used to check } \\
\text { the data validity. The findings of this study revealed that (1) there is an effect of } \\
\text { STEM-based online science learning on ETE students' communication skills, (2) } \\
\text { that most students are still in the Intermediate category for written } \\
\text { communication and "does not meet the Standards" for oral communication } \\
\text { skills, and (3) that students' communication skills in STEM-based science online } \\
\text { learning still need to be optimized. The study's findings suggest that ETE } \\
\text { lecturers in Indonesia should broaden their knowledge and perspectives in } \\
\text { STEM-based learning and communication management. Second, ETE lecturers } \\
\text { in Indonesia must take the assessment of communication skills more seriously. } \\
\text { Last but not least, the government, with the help of researchers, must devise an } \\
\text { excellent assessment system to overcome time constraints. The results of this } \\
\text { study revealed that STEM-based online science learning is being implemented. }\end{array}$ \\
\hline
\end{tabular}

(C) The Author(s). 2021

This work is licensed under a Creative Commons Attribution 4.0 International License 


\section{INTRODUCTION}

\section{Background}

Education is facing a number of increasingly serious challenges, in line with the evolution of the world's paradigm of what education means. One of the most significant challenges is that education must be capable of producing fully competent human resources. Unlike decades ago, the competencies expected of human resources professionals today are more focused on a few competencies, one of which is communication skills. This is one of the competencies that is emphasized in the twenty-first century, and it is one of the skills that a person must have when entering the workforce (Bybee, 2013). Human resources should be able to communicate in order to collaborate and communicate creative ideas at this time. Communication skills are seen as more than just soft skills; they are also seen as one of the keys to overcoming today's challenges. (Haryanti \& Suwarma, 2018). Communication skills are defined as the ability to effectively convey verbal information, criticism, and the ability to reflectively and interactively use and write in a variety of media and technologies. Collaboration, interpersonal skills, personal responsibility, social responsibility, and publicinterest thinking, as well as two-way communication, are all important aspects of effective communication. (Greenstein, 2012).

\section{Problem of Study}

The results of a study conducted by Marfuah (2017) on grade VII students at a junior high school in Depok City during the even semester of the 2015/2016 academic year demonstrate the lack of student communication skills in Indonesia, and it is also well known that students rarely receive assignments to make observations or assignments of natural objects and phenomena. Students are placed as recipients of information and the contents of the book are poured out so that when asked for arguments in the discussion process, students are unable to express their opinions, are insecure, and as a result, students do not understand the material, resulting in low learning outcomes. In a study conducted by Dipalaya et al. (2016), the same issue was discovered: learning Biology is still heavily geared toward developing and testing students' memory. Learning is often based on rote learning rather than student experience, causing students' abilities to be misunderstood as memorizing abilities, resulting in less-than-optimal communication skills. The teacher has recently begun to provide opportunities for students to communicate while learning, as evidenced by the frequent discussion and question-and-answer activities in class. However, the expected communication skills have not been fully developed during the learning process. Students are less interactive in their communication, use less technology, and deliver messages or information in a less assertive and effective manner.

Communication skills should be taught as part of the learning process, given their importance. STEM-based learning is an example of a successful learning strategy. Students are frequently required to communicate good ideas with peers, teachers, or other audiences to convey the results of the learning process they have gone through in this approach, which is based on Project-Based Learning. As a result, it is thought that the STEM approach will help students improve their communication abilities.

STEM learning is based on a multidisciplinary approach and Project Based Learning. The goal of STEM education is to prepare students to apply their knowledge to solve complex problems and to develop STEM skills. (Ritz \& Fan, 2015). Through the systematic integration of knowledge, concepts, and skills, the STEM learning approach is expected to produce meaningful learning for students. Students become better problem solvers, inventors, independent, logical thinkers, and have greater technological literacy as a result of the STEM approach. (Stohlmann et al., 2012);(Kelana et al., 2020). Students are expected to not only solve STEM-related problems, but also to solve a variety of complex problems that will help 
them develop their higher-order communication and thinking skills. STEM can also help students prepare for the needs of 21st-century human resources (Bybee, 2013);(Firdaus et al., 2020), even though it is still in the midst of the Covid-19 pandemic.

Covid-19 is a virus that has never been predicted before, and it is likely that it will become an endemic virus in the community. According to Dale Fisher, WHO Global Outbreak Warning and Response Network Official, the Covid-19 vaccine will most likely be available by the end of 2021. In this regard, the Indonesian Minister of Education and Culture issued Circular No. 4 of 2020 on the implementation of Education Policy in an Emergency for the Spread of COVID, which explains that students learn at home through distance learning to provide meaningful learning experiences (Kelana, J.B., Wardani, D.S., \& Wulandari, 2021).

\section{State of the Art}

In fact, studies on student communication skills have been carried out both in Indonesia and abroad. These studies include Hausberg et al. (2012) which conducts development and evaluation in improving the communication skills of medical students, Maryanti et al., (2012) examines the relationship between communication skills and student learning activities. In line with this, Dharmayanti (2013) investigated the use of role-playing techniques in improving student communication skills, Wardani et al. (2020) used a Projectbased learning model with a prop-making activity to improve students' written communication skills, and Thomas et al. (2009) developed SBAR communication techniques to improve medical students' communication skills. However, most of these studies focus on offline or face-to-face learning, and few have looked at communication skills in STEM via online learning.

\section{Gap Study \& Objective}

This study aims to identify the profile of communication skills of Elementary Teacher Education students in STEM-based Natural Science Online Learning as a first step in analyzing the effect of STEM-based learning on students' communication skills through online learning. Oral and written communication skills are included in the measured communication skills profile.

\section{METHOD}

Type and Design

This research is a pre-experimental research with a One-Shot case study design. The One-Shot Case Study design is a research design consisting of one group that is given treatment which then observes these results and the absence of a comparison group and randomization (Dantes, 2012; Sugiyono, 2012). The design of the one shot case study can be seen in Figure 1 (Fraenkel, J.R., and Weelen, 2008).

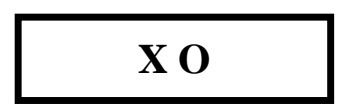

Figure 1: Pre-experimental research with a one-shot case study design

Note:

$\mathrm{X}$ : Treatment of independent variable

O: Observation or measurement of dependent variable

Convenience Sampling was used to select the sample for this study, which consisted of 25 Elementary Teacher Education (ETE) students from a university in Cimahi, Indonesia, during 
the 2018/2019 academic year. The study's independent variable is STEM-based online natural science learning, and the study's object is student communication skills.

STEM has been used in lectures for the past few semesters, but due to the Covid-19 pandemic in the middle of the even semester, lectures have been transferred to online learning while still incorporating STEM.

\section{Data and Data Sources}

The data gathered in this study is in the form of results from students' oral and written communication skills tests. Oral communication and written communication are the two types of communication skills that are assessed in students. Data collection on oral communication skills was carried out through a presentation process which was assessed based on a rubric adapted from the University of Baltimore (University of Baltimore, 2010) with 6 indicators, namely: 1) Organization, (2) Eye contact, (3) Delivery, (4) Conclusion, (5) Responsiveness, and (6) Multimedia Support. The results of the student presentations will then be analyzed as a whole and will divide the students into three categories of oral communication skills which can be seen in Table 1.

Table 1. Oral Communication Assessment Criteria

\begin{tabular}{cc}
\hline Total score & Category \\
\hline $16-18$ & Exeed the standard \\
$11-15$ & Meet the standard or avarage \\
$\leq 10$ & Failed to meet standard \\
\hline
\end{tabular}

While data on written communication skills was gathered through the creation of a report, which was then evaluated based on predetermined criteria, which consisted of: (1) Objectives, (2) Background of the Problem, (3) Idea Finding, (4) Making Process, (5) Testing Process, (6) Analysis, (7) Results, and (8) Conclusions and fulfilling the Format and Style requirements that have been determined. The results of processing grades from student reports are then categorized into several categories based on the rubric adapted from the University of Baltimore, with the scoring criteria which can be seen in Table 2.

Table 2. Written Communication Assessment Criteria

\begin{tabular}{cc}
\hline Total score & Category \\
\hline $25-30$ & Advance \\
$17-24$ & Intermediate \\
$9-16$ & Emerging \\
$\leq 8$ & Basic \\
\hline
\end{tabular}

Data collection technique

\section{Observation}

The observations used in this research are participatory observation and direct observation. The author evaluates both inside and outside of class activities by observing informants (lecturers). The author participates in lecturer activities when assessing students' oral communication skills which consists of 6 indicators

\section{Documentation}

The purpose of this study's documentation method is to obtain data through documentation, which entails studying documents related to all of the study's data requirements. The document used in this study is a document report on the results of 
project implementation carried out by each student to assess students' written communication skills which consists of 8 indicators.

\section{Data Validity}

Furthermore, a T-Test (paired sample t-test) was used in this data processing activity to see if project-based learning improved the writing skills of elementary school teacher candidates' science teaching materials. HO is accepted and interpreted as not having a significant improvement in the writing skills of science teaching materials for elementary school teacher candidates using the project-based learning model if the Asymp.Sig value is (2-tailed)>, where $\alpha=0.05$.

\section{Data analysis}

The data analysis method used consisted of descriptive analysis of the data and hypothesis testing using the t-test. The hypotheses proposed in this study are: (1) there is an effect of using STEM-based online science learning on the oral communication skills of PGSD students, (2) there is an effect of using STEM-based online natural science learning on ETE students' written communication skills.

\section{RESULT}

The lecture begins by allowing students to identify problems using a student worksheet, which the lecturer guides through zoom in order to complete. The students were confronted with the problem of discovering a village that lacked access to electricity and relied on kerosene lamps, which are a non-renewable source of energy. It was also explained that because non-renewable energy sources will eventually run out, the price of fuel oil will continue to rise, and because the village is remote, there is no electricity serviceHowever, other suitable alternative energy sources, such as wind and water, are available in the village. Students are also required to create problem-solving designs in order to create tools that use alternative energy as solutions to problems they have encountered individually at this meeting. Students will begin to turn the results of their thoughts into products that can individually solve these problems at the second meeting, giving them the freedom to choose which designs to use. Students begin making tools individually after creating a complete design with scale and size. The product designs that each student is expected to create are propeller designs for wind power plants or turbine designs for hydropower plants that can produce the most electrical energy. Each student must analyze how to make their windmill produce more electrical energy once the propeller or mill in the product can move and produce electrical energy. Each student is allowed to redesign and remake the product or improve the product that has been made so that it can produce more electrical energy at the fourth and fifth meetings.

At the sixth meeting, students were asked to present the products they had created individually after all of the learning activities had been completed. This meeting will also include a presentation-based assessment of students' oral communication skills. Then, as a means of evaluating written communication skills, students are asked to prepare a structured report based on the product that has been created.

According to research, the majority of students (56\%) still fall into the "failed to meet standards" category. None of the students, on the other hand, "exceed the standards," and some of the others "meet the standard." This suggests that STEM-based science education can help students improve their oral communication skills, but the implementation process still needs to be improved. The data can be seen in Table 3. 
Table 3. Analysis of Oral Communication Skills

\begin{tabular}{ccc}
\hline Total score & $\begin{array}{c}\text { Number of } \\
\text { students }\end{array}$ & $\%$ \\
\hline Exceed the standard & - & \\
Meet the standard or average & 14 & 56 \\
Failed to meet standard & 11 & 44 \\
\hline
\end{tabular}

Table 3 shows that more than half of the students have oral communication skills that fall short of the minimum requirements. This is due to a lack of opportunities for students to practice their oral communication skills in the past. Aside from that, this can occur because not all knowledge can be conveyed through oral presentations. Table 4 shows the results of written communication skills testing.

Table 4. Analysis of Written Communication Skills

\begin{tabular}{ccc}
\hline Level & Number of students & $\%$ \\
\hline Advanced & - & \\
Intermediate & 13 & 52 \\
Emerging & 8 & 32 \\
Basic & 4 & 16 \\
\hline
\end{tabular}

Table 4 shows that the majority of students are in the intermediate category, with thirteen students $(52 \%)$ in the intermediate category, eight students (32\%) in the emerging category, four students (16\%) in the Basic category, and no students in the advanced category. This indicates that, while the majority of students are already in the Intermediate category, there is still room for them to improve their written communication skills through STEM-based natural science online learning in order to advance to the Advanced category.

A. Tujuan

Menemukan solusi permasalahan dengan membuat suatu alat yang dapat membantu menyelesaikan masalah tersebut

Figure 2: Example of Students' Response of a question on Purposes of Making aProduct which earns a score of 1 . In English, it equals as "Making a tool to solve the problem in order to find a solution"

Figure 2 shows an example of a student's response to the 'Objectives' section with a score of one, indicating that the student is at the Emerging level. The explanation receives a score of one because it does not meet the criteria. Meanwhile, Figure 3 depicts an example of a student's response for the 'Objectives' section with a score of two points at the Intermediate level.

A. Tujuan

Menemukan solusi agar desa tersebut mendapat energi tambahan berupa energi listrik karena sebelumnya masih menggunakan lampu dengan bahan bakar minyak tanah

Figure 3: Example of Students' Response of a question on Purposes of Making a Product which earns a score of 1. In English, it equals as "find a solution to provide the village with additional energy in the form of electricity, as it previously relied solely on kerosene as a fuel source" 
"Being able to make simple power generation technology using the principle of energy change through the use of natural energy sources based on problem analysis," is the answer to the 'Objectives' section that students are expected to write. Keywords such as energy crisis, alternative energy, natural energy, and power generation are also likely. It is also possible to write it directly by mentioning windmills or watermills. Figure 2 only states that the purpose of making the product is "making a tool to solve the problem in order to find a solution," without elaborating on what problems are encountered, what tools will be made, and what the conditions and situations that are occurring.

Meanwhile, in Figure 3, the response appears brief, but the explanation includes several keywords, such as "additional energy." The student then mentioned the village's previous conditions, implying that the students already knew what problems the village was facing. Despite the fact that the answers to the students' explanations were incomplete, the explanation indicated that students could write down the product's objectives based on problem analysis.

The data were found to be normally distributed and not homogeneous based on the results of the normality and homogeneity tests, so the mean similarity test could be continued using the Mann-Whitney U-test as an alternative to the free sample t-test through the SPSS 20 program with a significance level of 0.05 . Table 3 displays the MannWhitney U-Test results.

Table 5. The Mann-Whitney U-Test

\begin{tabular}{lr}
\hline \multicolumn{2}{c}{ Test Statistics $^{\mathrm{a}}$} \\
\hline Pos - Pre \\
\hline Asymp. Sig. (2-tailed) \\
a. Mann-Whitney Signed Ranks Test \\
b. Based on negative ranks. \\
\hline
\end{tabular}

Only the two-party (2-tailed) test meets the test criteria based on the Mann-Whitney test of the student report scores. The null hypothesis is rejected in Table 3 because Asmp. Sig. (tailed) has a significance of 0.001 and 0.001 is smaller than 0.05 . This means that the application of STEM-based online science learning has an impact on ETE students' communication skills.

\section{DISCUSSION}

According to Table 3, more than half of the students are unable to communicate verbally. They do not meet the requirements, as evidenced by the findings. This happened because students had not had enough opportunities to practice their oral communication skills in the past. When students have the opportunity to speak in front of an audience, they will feel nervous, and when asked to give a presentation, they will feel under pressure. (Saenab et al., 2017). This causes students to forget what they want to say when speaking in front of a group, even if they are in an online learning environment. Receiving and transmitting information, as well as gathering data, are all communication skills (llyas, 2013). Because STEM relies on a Project-Based Learning approach, students are frequently required to communicate ideas with colleagues, teachers, or other audiences to convey the result of the learning process, students' oral communication skills have been honed in STEM-based online science learning. Project-based learning in STEM, according to Priansa (2015) , always includes presentations or performances. This presentation process, like the 
previous project design presentation stage, allows students to share tasks in providing information about their project results. Information is communicated communicatively via poster media, attracting other members to actively ask questions. The question-and-answer process also increases student knowledge of the concepts covered (Saenab et al., 2017). Based on this description, it is possible to conclude that by implementing STEM consistently in online learning, students' oral communication skills will be able to meet or exceed standards.

Meanwhile, according to Table 4, half of the students have intermediate written communication skills, while the other half have emerging or basic skills. The intermediate category indicates that some students can communicate in writing, as evidenced by the individual reports on project results. It is possible to see how students determine goals, background problems, idea generation, project creation process, trial process, analysis, results, and conclusions, as well as how they adhere to the predetermined format and style. Students will gain experience and basic concepts from STEM project activities that will help them understand problems and find solutions. Improved written communication skills as a result of positive treatment/values from STEM learning activities using a project-based learning model. According to Afriana et al. (2016), Project-Based Learning in STEM has several benefits, including: encouraging students to do meaningful work; able to encourage students to improve collaborative skills in communication; increasing motivation in learning; improving student skills to manage learning resources; making students more able to develop and practice communicating skills; providing students with experiential learning through practice and project organization; Students will understand the material and be able to communicate their understanding through writing as a result of thi.

Figure 2 depicts the responses, which show that students were unable to elaborate on the problems encountered, the tools that will be created, and the conditions and situations that occurred. One aspect of creative thinking skills is the ability to elaborate, which allows a person to develop, enrich, and detail ideas (Guilford, 1950; Guilford, 1967; Beck, 2011). Students can learn to elaborate in presentations where they present their work or products. The presentation process in STEM learning can consistently train students to think fluently and elaborately, which can be expressed verbally and in writing. (Nafiah \& Suyanto, 2014; Nurcholis et al., 2013).

Furthermore, in Figure3, students were able to analyze the problems encountered and understand that these problems require solutions in one aspect but are unable to find the correct solution. Even though the answers to the students' explanations were incomplete, the explanation indicated that students could write down the product's objectives based on problem analysis.

The ability of students to critically review problems from various points of view is closely related to their ability to analyze problems (Yuniarti \& Hadi, 2015). Project-based learning can help you develop the ability to analyze problems in stages (Maida, 2011). This is due to the fact that in project-based learning, students must be able to develop their knowledge and skills through a process of problem analysis and investigation with structured open questions in order to be able to apply knowledge to produce a product (Kelana \& Wardani, 2021).

\section{CONCLUSION}

Previous research on communication skills was limited to face-to-face learning dimensions and primarily focused on one aspect of oral communication. The current study revealed the implementation of STEM-based online science learning that is conducted online. The current study's findings would be critical for all elementary education parties to develop an effective solution to this problem. 
There are several limitations to the study. Initially, it is only conducted on ETE students in a single batch at a single university, so it cannot be generalized completely to all ETE students. Second, because the study lasted less than a year, the data was not entirely comprehensive. Future studies on implementing social attitudes assessment would benefit from more representative informants (from various universities) over the course of a year. Three recommendations are made by this study. First, ETE lecturers in Indonesia must broaden their knowledge and insights into STEM-based learning and communication management. Second, ETE lecturers in Indonesia must take communication skills assessment more seriously. Finally, the government, with the help of researchers, must create an excellent assessment system to address time constraints.

\section{REFERENCES}

Afriana, J., Permanasari, A., \& Fitriani, A. (2016). Penerapan Project Based Learning Terintegrasi STEM Untuk Meningkatkan Literasi Sains Siswa Ditinjau Dari Gender (Implementation Of STEM Integrated Project Based Learning To Improve Students' Scientific Literacy In Terms Of Gender). Jurnal Inovasi Pendidikan IPA, 2(2), 202. https://doi.org/10.21831/jipi.v2i2.8561

Beck, J. (2011). Cognitive behavior therapy: Basics and beyond. London: The Guilford Press. Bybee, R. W. (2013). The Case for STEM Education: Challenges and Opportunities. Virginia: NSTA Press.

Dantes, N. (2012). Metode Penelitian (Research Method). Yogyakarta: Andi Offset. Dharmayanti, P. A. (2013). Teknik Role Playing Dalam Meningkatkan Keterampilan Komunikasi Interpersonal Siswa SMK (Role Playing Techniques to Improve Interpersonal Communication Skills of Vocational School Students). Jurnal Pendidikan Dan Pengajaran. 46(3), 256-265. http://dx.doi.org/10.23887/jppundiksha.v46i3.4228.

Dipalaya, T., Susilo, H., \& Corebima, A. D. (2016). Pengaruh Strategi Pembelajaran PDEODE (Predict-Discuss-Exolain-Observe-DiscussS- Explain) pada Kemampuan Akademik Berbeda terhadap Keterampilan Komunikasi Siswa (The Effect of PDEODE (PredictDiscuss-Exolain-Observe-DiscussS- Explain) Learning Strategies on Different Academic Abilities on Students' Communication Skills). Jurnal Pendidikan, 1(9), 1713-1720. http://dx.doi.org/10.17977/jp.v1i9.6723

Firdaus, A. R., Wardani, D. S., Altaftazani, D. H., Kelana, J. B., \& Rahayu, G. D. S. (2020). Mathematics learning in elementary school through engineering design process method with STEM approach. In Journal of Physics: Conference Series, (Vol. 1657, No. 1, 012044). IOP Publishing. https://doi.org/10.1088/1742-6596/1657/1/012044

Fraenkel, J.R., and Weelen, N. E. (2008). How to Design and Evaluate research in Education. McGraw-Hill.

Greenstein, L. (2012). Assessing 21st century skills: A guide to evaluating mastery and authentic learning. california: Corwin SAGE Company.

Guilford, J. P. (1950). Creativity. American Psychologist, 5(9), 444-454. https://doi.org/10.1037/h0063487

Guilford, J. P. (1967). Creativity: Yesterday, Today and Tomorrow. The Journal of Creative Behavior, 1(1), 3-14. https://doi.org/10.1002/j.2162-6057.1967.tb00002.x.

Haryanti, A., \& Suwarma, I. R. (2018). Profil Keterampilan Komunikasi Siswa Smp Dalam Pembelajaran IPA Berbasis STEM (Profile of Junior High School Students' Communication Skills in STEM-Based Natural Science Learning). WaPFi (Wahana Pendidikan Fisika), 3(1), 49-54. https://doi.org/10.17509/wapfi.v3i1.10940

Hausberg, M. C., Hergert, A., Kröger, C., Bullinger, M., Rose, M., \& Andreas, S. (2012). Enhancing medical students' communication skills: Development and evaluation of an undergraduate training program. BMC Medical Education. 12(19), 1-9. 
https://doi.org/10.1186/1472-6920-12-16

Ilyas, A., \& Marjohan. (2013). Hubungan Antara Keterampilan Komunikasi Dengan Kecemasan Berbicara Di Depan Umum (The Relationship Between Communication Skills And Public Speaking Anxiety). Konselor. 2(1), 273-278. https://doi.org/10.24036/02013211203-0-00

Kelana, J.B., Wardani, D.S., \& Wulandari, M. A. (2021). Penggunaan Aplikasi Zoom Meeting Di Masa Pandemi Covid-19 (Use of the Zoom Meeting Application During the Covid19 Pandemic). Elementary, Jurnal, 4(1), 18-22. http://journal.ummat.ac.id/index.php/elementary/article/view/3520.

Kelana, J. B., \& Wardani, D. S. (2021). Model Pembelajaran IPA SD (Elementary Science Learning Model). Cirebon: Edutrimedia Indonesia.

Kelana, J. B., Wardani, D. S., Firdaus, A. R., Altaftazani, D. H., \& Rahayu, G. D. S. (2020). The effect of STEM approach on the mathematics literacy ability of elementary school teacher education students The effect of STEM approach on the mathematics literacy ability of elementary school teacher education students. In Journal of Physics: Conference Series, (Vol. 1657, No. 1, 012006). IOP Publishing. https://doi.org/10.1088/1742-6596/1657/1/012006

Maida, C. A. (2011). Project-based learning: A critical pedagogy for the twenty-first century. Policy Futures in Education, 9(6), 759-768. https://doi.org/10.2304/pfie.2011.9.6.759

Marfuah, M. (2017). Meningkatkan Keterampilan Komunikasi Peserta Didik melalui Model Pembelajaran Kooperatif Tipe Jigsaw (Improve Students' Communication Skills through the Jigsaw Type Cooperative Learning Model). Jurnal Pendidikan IImu Sosial. 26(2), 148-160. https://ejournal.upi.edu > jpis > article > download > pdf.

Maryanti, S., Zikra, ., \& Nurfarhanah, . (2012). Hubungan antara Keterampilan Komunikasi dengan Aktivitas Belajar Siswa (Relationship between Communication Skills and Student Learning Activities). Konselor, 1(2), 1-8. https://doi.org/10.24036/0201212700-0-00.

Nafiah, Y. N., \& Suyanto, W. (2014). Penerapan model problem-based learning untuk meningkatkan keterampilan berpikir kritis dan hasil belajar siswa (Application of problem-based learning models to improve critical thinking skills and student learning outcomes). Jurnal Pendidikan Vokasi, 4(1), 125-143. https://doi.org/10.21831/jpv.v4i1.2540

Nurcholis, A., Suciati, \& Indrowati, M. (2013). Implementation of Prolem Based Learning (PBL) Model Accompanied by Scientific Articles for Increasing Creative Thinking Ability Student in X3 Class SMAN 2 Boyolali Academic Year of 2012/2013. Bio-Pedagogi, 2(2), 58-67. https://jurnal.uns.ac.id/pdg/article/view/5300/4698

Priansa, D. J. (2015). Manajemen Peserta Didik dan Model Pembelajaran (Student Management and Learning Models). Bandung: Alfabeta.

Saenab, S., Yunus, S. R., \& Virninda, A. N. (2017). PjBL untuk Pengembangan Keterampilan Mahasiswa: Sebuah Kajian Deskriptif Tentang Peran PjBL dalam Melejitkan Keterampilan Komunikasi dan Kolaborasi Mahasiswa (PjBL for Student Skills Development: A Descriptive Study of the Role of PjBL in Boosting Student Communication and Collaboration Skills). Makassar: Seminar Nasional Lembaga Penelitian UNM (National Seminar of the UNM Research Institute.)

Stohlmann, M., Moore, T., \& Roehrig, G. (2012). Considerations for Teaching Integrated STEM Education. Journal of Pre-College Engineering Education Research. Journal of Pre-College Engineering Education Research 2(1), 28-34. https://doi.org/10.5703/1288284314653

Sugiyono. (2012). Metodologi Penelitian Pendidikan Pendekatan Kuantitatif, Kualitatif dan $R \& D$ (Educational Research Methodology Approaches to Quantitative, Qualitative and R \& D). Bandung: Alfabeta. 
Thomas, C. M., Bertram, E., \& Johnson, D. (2009). The SBAR communication technique: Teaching nursing students professional communication skills. Nurse Educator. 34(4), 176-180. https://doi.org/10.1097/NNE.0b013e3181aaba54

University of Baltimore. (2010). Assessment Rubrics for Communication: Oral Communication Skills. https://www.ubalt.edu/merrick/studentresources/rubrics.cfm.

Wardani, D. S., Fauzi, M. R., Zafira, R., \& Kurniawati, D. (2020). Creating Props: Improving Writing Skills of Teaching Materials of Elementary Teacher Education Students through Project-Based Learning Model. Mimbar Sekolah Dasar, 7(2), 216-234. https://doi.org/10.17509/mimbar-sd.v7i2.26334

Yuniarti, T. \& Hadi, S. (2015). Peningkatan Kemampuan Analisis Pokok Bahasan Masalah Ekonomi Dengan Model Pembelajaran Problem Based Learning (Pbl) Siswa Sma Negeri 1 Bandongan Kabupaten Magelang (Increasing the Ability to Analyze the Subjects of Economic Problems with the Problem Based Learning (Pbl) Learning Model of SMA Negeri 1 Bandongan Students in Magelang Regency). Dinamika Pendidikan, 10(1), 76-87. https://doi.org/10.15294/dp.v10i1.5096 